\title{
Szathmári István emlékezete
}

Szathmári Istvántól búcsúzva a nem csupán életévekben mérten nem mindennapi, de munkában és eredményekben is különösen gazdag életpályára, tudományágunk több területének müvelőjére, a tudós tanárra, szakmából és emberségből mutatott példájára egyaránt emlékezünk. A számos figyelemre méltó terület és felmerülö szempont közül hadd emeljek ki magam itt leginkább egyet, mely pályájának meghatározó, szervező eleme volt. Szomorú kötelességnek téve eleget, sokak nevében búcsúzom Szathmári Istvántól, az ELTE egykori professzorától.

Szathmári tanár úr 1948-tól állt a katedrán. Három évig tanított egy debreceni közgazdasági középiskolában, majd került fel Pestre, Bárczi Géza és Pais Dezső ajánlásával, az ekkor létrehozott Idegen Nyelvek Főiskolájára. Itt immár a magyar tanszék vezetöjeként szervezte és indította meg az oktatást, s pár év alatt föiskolai jegyzetek sorát írta meg hallgatóinak. A föiskola megszünésével, 1955-ben került az ELTE néhány évvel korábban megalakult, II. Számú Magyar Nyelvészeti Tanszékére, melyet egykori debreceni professzora és szeretett mestere, Bárczi Géza vezetett, s ahol ismerős szakmai és kollegiális közeg fogadta. Kibontakozó szakmai munkásságát részben a kapott indíttatás, a saját érdeklődés, részben pedig a mindenkori szükséglet, az aktuális igények és feladatok határozták meg. Utóbbiak vezették el az idővel legjellemzőbb kutatási területévé váló stilisztika irányába is.

1970-ben, amikor az ELTE magyar nyelvészeti tanszékei közt megtörtént a szakosodás, lett az ekkortól Mai Magyar Nyelvi Tanszék néven müködő egység vezetője. Közel másfél évtizeden át, 1984-ig töltötte be e tisztséget, melynek révén nevéhez kötődik a tanszék leíró nyelvészeti profiljának kialakítása. A tanszéken müvelt szakterületekhez kapcsolódó tankönyvek, segédkönyvek szerzőjeként, szerkesztőjeként is tevékenyen vett részt a leíró nyelvészeti oktatás korszerüsítésében. Tanszékvezetői ideje alatt kerültek be olyan tárgyak a magyar szakos oktatásba, mint például a szövegtan, melyek azóta a korszerủ nyelvészeti képzés elengedhetetlen részévé váltak.

A hetvenes évek elején szervezte meg, majd vezette évtizedeken át a tanszék mellett müködő Stíluskutató csoportot, mely a hazai stilisztika művelésének biztosított felbecsülhetetlen jelentőségü színteret és átfogó keretet, s mely aztán további tanszéki kutatómühelyeknek és csoportoknak szolgálhatott mintául. Szintén 1970től, megindulásától fogva, s ugyancsak évtizedeken át szerkesztette az egyetem Annales ... Sectio Linguistica néven ismert idegen nyelvü nyelvészeti évkönyvét, mely a Bölcsészkaron folyó nyelvtudományi kutatásokról volt hivatott képet adni a nemzetközi - nem utolsó sorban az akkori vasfüggönyön túli - tudományosság számára.

Szathmári Istvánt azonban nem csupán a szükebb értelemben vett tanszéki, illetve szakmai feladatok találták meg. Tanszékén végzett oktató- és kutatómunkája mellett, a hatvanas évek elején néhány évig az egyetem Magyar Nyelvi Lektorátusát is vezette. 1969 és 1975 közt az ELTE akkortájt 56 tanszékbőll álló Bölcsészettudományi Karának oktatási dékánhelyettese volt. Az ezzel járó feladatokat is 
szívvel-lélekkel csinálta, s mint vallotta, ezeket sem tekintette puszta adminisztrációnak. A következő négy évben, 1975 és 1979 között pedig a Kar dékánjának tisztségét töltötte be. Ebben az időszakban foglalkozott kutatóként a régi magyar nyelvtanírók munkásságával. A napjait így továbbra is rendszerint az Egyetemi Könyvtárban kezdte, meghagyva titkárnöjének, hogy ott hívják, ha sürgős intéznivaló akadna. Délutánjait a tanítás, a további szakmai feladatok és a dékáni teendők ellátása töltötte ki.

Egyetemi tisztségeivel összefüggésben is foglalkozott olyan kérdésekkel, mint az egyetemek feladatai, a magyar szakosok nyelvészeti képzésének szempontjai vagy éppen a középiskolaitanár-továbbképzés megszervezése és tapasztalatai. Az egyetemekre vonatkozólag az oktatás és kutatás szerves egységét vallotta mindig is; az akadémiai kutatóintézetekben nem müvelt diszciplínákkal való foglalkozás és az interdiszciplináris, komplex kutatások fontosságát hangsúlyozta; saját tudományterületén a nyelvhasználat-központú nyelvészeti oktatás megvalósítását szorgalmazta.

Dékáni időszakához kötődött egyebek mellett a pesti egyetemen a finn szakos képzés előkészítése is. Ez szolgált azután indíttatásként, egyfajta kölcsönösség jegyében is, a Helsinki Egyetem számára az ottani magyar nyelv és irodalom főszak megindításához. Ennek megszervezésére, vendégprofesszorként Szathmári tanár urat hívták meg a finn fóvárosba, ahol így 1983-tól oktatott magyar nyelvet és irodalmat az egyetemi hallgatóknak. A budapesti tanszékvezetés feladatát ekkor adta át Fábián Pálnak. Hat éves finnországi vendégprofesszorság után tért haza, s oktatóként vissza az ELTE-re.

Mikor a 90-es évek közepén - huszonöt évvel ezelőtt! - nyugdíjba vonult, a tanítást és a kutatómunkát természetesen továbbra sem adta fel. Professor emeritusként, még néhány évvel ezelőtt is, a tőle megszokott lendülettel és odaadással tartotta szemináriumi óráit a magyar szakos hallgatóknak. „Meg vagyok áldva vagy verve a tanítással" - fogalmazta meg, a rá jellemző derüvel és öniróniával, jónéhány évvel ezelőtt egy pódiumbeszélgetés során is. S volt óriási szerencséje a magyar szaknak - ahogyan azt a beszélgetőtárs egyetemi hallgató tette hozzá -, hogy nyelvészettel foglalkozott, s nálunk tanított.

Szathmári István - életpályája során több felsőoktatási intézményben is - egyetemi hallgatók egymást követő nemzedékeinek volt tanára, kutatók generációinak mestere. Igazi filosz, aki a filoszságot és a tudomány müvelésének - de az egyéb feladatok elvégzésének is - emellé társuló éthoszát alapkövetelménynek tekintette, és meg is testesítette. Olyan tudós és ember volt, akinek személye összekötő kapocs, híd tudott lenni különböző tudományterületek, irányzatok és témák, s mindezek müvelöi közt. Természetes közvetlensége és belső derüje, önmagával és másokkal szembeni igényessége, jóindulata és korrektsége mindennek biztos alapját jelentette.

Egykor, az ELTE-s intézeti karácsonyok alkalmával hagyományosan egymás mellett foglaltak helyet az ünnepi asztalnál nyugdíjas professzoraink: Benkő Loránd, Fábián Pál és Szathmári István. Egy olyan nagy nyelvész nemzedék tagjai, amelytől most, Szathmári tanár úr távozásával kell végleg búcsút vennünk.

Az az asztal már mindörökre üres marad. De emlékét nem felejtjük.

Kedves Tanár úr, nyugodj békében!

FARKAS TAMÁS

ELTE Eötvös Loránd Tudományegyetem 